\title{
DEPENDENCE OF CARRIAGEWAY CROSSFALL ON OPERATING SPEED
}

\author{
Scientific paper / Znanstveni rad \\ Ivan Lovrić \\ (Received: 22 March 2019; accepted: 04 June 2019) \\ University of Mostar, Faculty of Civil Engineering, Associate Professor \\ Corresponding author: ivan.lovric@gf.sum.ba or ivan.lovric40@gmail.com \\ Boris Čutura \\ University of Mostar, Faculty of Civil Engineering, Assistant Professor \\ Dražen Cvitanić \\ University of Split, Faculty of Civil Engineering, Architecture \& Geodesy, Full Professor
}

\begin{abstract}
This paper describes a rational approach to improve the existing guidelines for road design in the regions of Slovenia, Croatia, Bosnia and Herzegovina, and Serbia in order to determine the carriageway crossfall in curves. In these guidelines there are certain shortcomings in determination of crosfall in comparison to some other European countries guidelines. During the last decades, worldwide and in Europe specifically, significant studies have been conducted on the issue of the operating speed and its implementation into the design process. Most European countries have been implementing this concept. The new German guidelines went a step further and introduced a new concept of a self-explaining class road. Using the results of research carried out in Croatia, this work focuses only on a determination of the carriageway crossfall based on operating speed, separately observing new and existing roads. Whereas the new road segments require implementing the principle of a consistent route, an existing road network can be safely improved only by introducing the criteria of the determination of crossfall in curves based on the operating speed.
\end{abstract}

Keywords: carriageway crossfall; operating speed; new segment; existing road network

\section{POPREČNI NAGIB KOLNIKA U FUNKCIJI OPERATIVNIH BRZINA}

Sažetak: U radu se objašnjava mogući koncept racionalnog pristupa poboljšanju postojećih pravilnika za projektiranje cesta u regiji (Slovenija, Hrvatska, Bosna i Hercegovina, Srbija) s gledišta određivanja poprečnog nagiba kolnika u krivinama. Analizirani su nedostatci u usporedbi s nekim europskim pravilnicima. Naime, u posljednjim desetjećima u svijetu i Europi napravljena su važna istraživanja na temu operativnih brzina i njihovog uvođenja u postupak projektiranja. $U$ većinu pravilnika implementiran je taj koncept. $U$ novim njemačkim smjernicama otšlo se korak dalje, odnosno uveden je novi koncept „samoobjašnjavajućih " (self-explaining) klasa cesta. Koristeći se i rezultatima istraživanja provedenih u Hrvatskoj, u radu se ograničilo samo na poprečni nagib kolnika u funkciji operativne brzine. Odvojeno se promatraju nove dionice koje zahtijevaju i uvođenje principa konzistentnosti trase, od dionica postojeće mreže cesta koje je moguće sigurnosno poboljšati samo uvođenjem kriterija određivanja poprečnog nagiba u krivinama temeljem operativne brzine.

Ključne riječi: poprečni nagib; operativna brzina; nova dionica; postojeća mreža 


\section{INTRODUCTION}

In the road network two-lane rural roads have the highest percentage. Unlike motorways that have a clearly defined function and safety rules and criteria during the planning, design, construction, and exploitation phases, two-lane roads have no unambiguous definitions of the functionality and design solutions, and in terms of traffic safety, the problems are more difficult.

Numerous studies have shown that approximately $50 \%$ of traffic accidents occur owing to an inadequate design of the horizontal alignment [1-3]. Many guidelines [4-6], do not adequately define how to obtain a consistent road segment. Road segment consistency provides safe driving conditions at the desired speed across the route, whereas inconsistency is reflected when drivers need to slow down for a safe connection to the next road element, thus increasing the likelihood of an accident [7].

One of the key steps to achieving consistency is the implementation of the operating speed in the design process. Many studies [8-11] have shown that the operating speeds along curves with a radius larger than the minimum are greater than the design speeds. This problem is most noticeable in a sharp curve following the flat curve where the operating speed is greater than the design speed and the radial friction coefficient ( $\left.f_{R}\right)$ between the tires and the pavement significantly exceeds the allowed values. The subject of this article is an analysis of the carriageway crossfall as a function of the speed, which is defined differently in different guidelines [4-6, 12] (basic, computational, project, design, and predictable speeds). These speeds from the guidelines are referred as design speeds below, while speed of $85 \%$ most faster driver will be defined as operating speed $\left(V_{85}\right)$.

Studies conducted in Croatia $[8,13,14]$ also confirm the fact that operating speeds are greater than the design speed. In this particular case (Figure 1a), for a road section with a design speed of $60 \mathrm{~km} / \mathrm{h}$, the limit value of the radius, where the operating and design speeds became equal, is approximately $300 \mathrm{~m}$ [13]. The differences between the operating and design speeds results in an exceedance of the allowed $f_{R}$ values (Figure $1 \mathrm{~b}$ ). The values of the activated radial friction coefficients in all curves exceed twice the permissible values and are significantly higher than the maximum values.

$$
\mathrm{v}[\mathrm{km} / \mathrm{h}]
$$

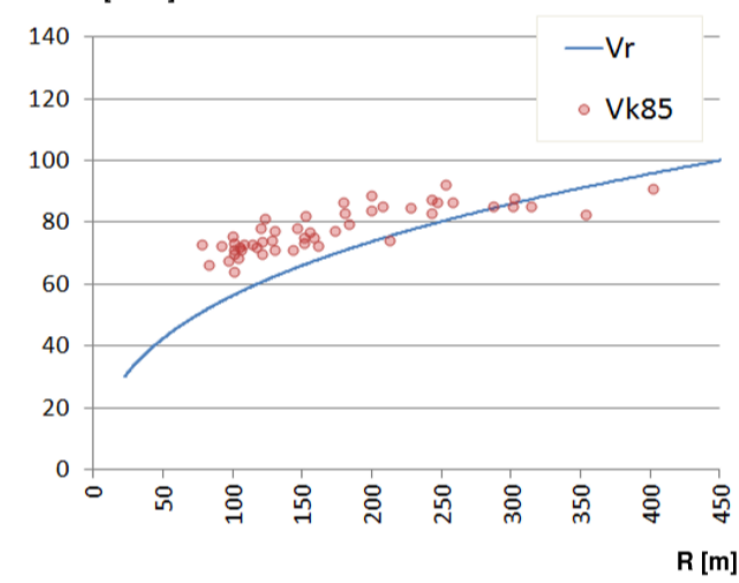

$f_{R}$

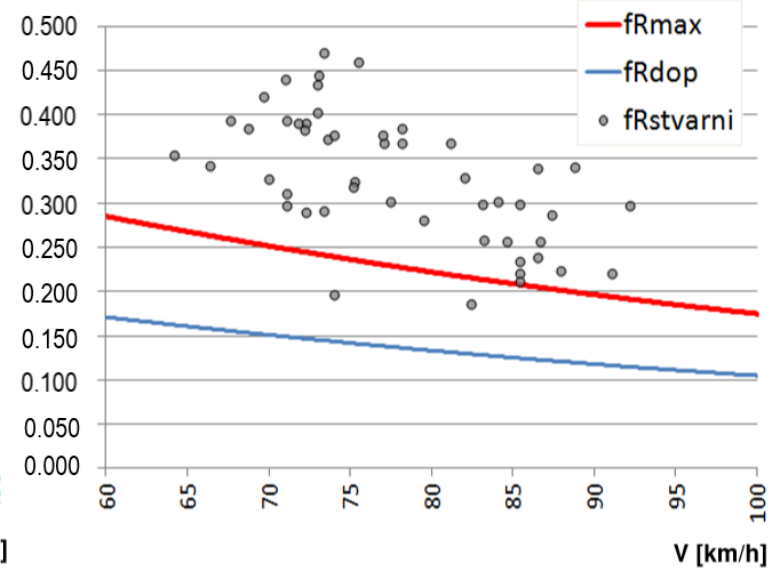

Figure 1 a) Relationship between design $\left(V_{r}\right)$ and operating $\left(V_{k 85}\right)$ speeds along the horizontal curves; $\left.b\right)$ relationship between the real radial friction coefficients ( $\left.f_{R s t v a r n a}\right)$ and the maximum ( $f_{R \max }$ ) and allowed ( $\left.f_{\text {Rdop }}\right)$ coefficients for the operating speeds [13]

Furthermore, for radii greater than the minimum, it is necessary to determine the most favorable ratio of the crossfall and radial friction coefficient according to the operating speed. In the guidelines of different countries [46 , 12] there are considerable differences in the choice of speed according to which the crossfall and $f_{R}$ values are calculated. Some road design guidelines, such as for old German [15] and Australian [16] roads, recognize this problem by using the $85^{\text {th }}$ percentile operating speed obtained through a field survey. The operating speed is defined as the speed below which $85 \%$ of the vehicles actually drive under free flow conditions. However, some other guidelines for a road design [4-6] use the theoretical value of the speed, herein called the design speed, rather than the $85^{\text {th }}$ percentile operating speed. For example, the Croatian guidelines define project $\left(V_{p}\right)$ and design $\left(V_{r}\right)$ speeds. The design speed is defined as the maximum expected speed under free flow conditions that can be 
achieved with sufficient safety on a particular part of the road segment depending on its horizontal and vertical characteristics. This is was determined from the basic equation of the vehicle stability along horizontal curves, as a function of the applied curve radius or largest applied longitudinal grade.

The Croatian guidelines also define the design speed as a criterion for determining the super-elevation and stopping sight distance and provide consistency criteria in terms of the design and project speed consistency and the consistency of the design speeds within a single road section. The problem is that this design speed (which is a theoretical value) is less than operating speed for radii of less than $300 \mathrm{~m}$, as mentioned earlier.

The choice of unrealistically low values of these speeds results in the application of insufficient crossfalls in the curves, leading to a greater friction resistance of the vehicle in order to keep the circular motion than the driver expects. This can lead to driver insecurity and braking, thus triggering the friction component in the longitudinal direction, which reduces the available radial friction resistance and increases the possibility of a single vehicle runoff-road accident. Therefore, a good road project, apart from the consistency of the alignments, must match the crossfall values and engaged radial friction resistance with real speeds.

This article analyzes only the application of the crossfall in curves of radii larger than the minimum using the results of the above-mentioned research and guidelines of certain countries in the region of Slovenia, Croatia, Bosnia and Herzegovina, and Serbia, as well as in Europe to compare the disadvantages of the existing guidelines in the region. The conclusions provide a way to improve such guidelines.

\section{REVIEW AND ANALYSIS OF THE GUIDELINES}

In this paper, the application of the carriageway crossfall according to two groups of guidelines is analyzed. The first group has the criterion of an optimal ratio of the crossfall and radial friction coefficient in such a way that they retain the maximum value of the crossfall to a particular radius, for which surveys have shown [13] that the design and operating speeds reach almost the same values (Figure 1). German [17], Austrian [18], and Serbian [12] guidelines were selected. The second group of cross fall guidelines is determined based on the radial stability conditions of a vehicle based on the design speeds without considering the operating speed. Bosnian and Herzegovinian [4], Croatian [5], and Slovenian [6] guidelines were selected from this group.

\subsection{First group of guidelines}

The German guidelines were made separately for the design of the motorways (RAA), rural roads (RAL) [17], and urban roads (RAST). The graph in Figure 2 refers to rural roads divided into four design classes (EKL 1 to EKL 4) and a speed range of 110 to $70 \mathrm{~km} / \mathrm{h}$. The continuous line represents free road segments, whereas the dashed line is for zones of intersections. The change in the crossfall from a maximum of $7 \%$ to a minimum of $2.5 \%$ for all mentioned road design classes and their speeds range from a radius of 350 to 1,000 m. The new German guidelines introduced a new approach, which are briefly described at the end of this paper because their concept is not directly related to the subject of this article.

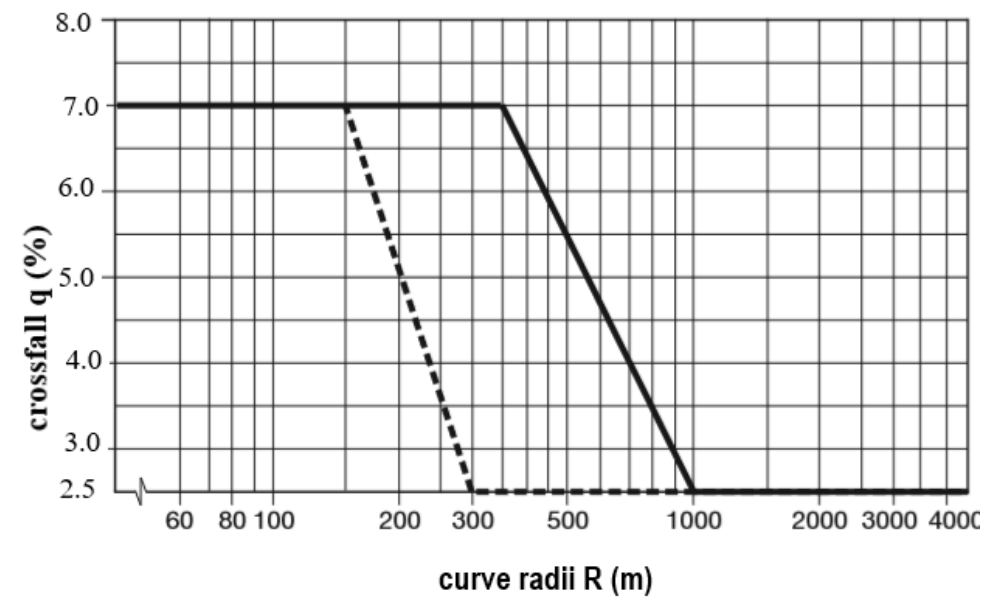

Figure 2 Crossfall as a function of curve radius in RAL [17] 
The Austrian guidelines (Table 1) divide the roads into federal roads with maximum speeds of greater than $100 \mathrm{~km} / \mathrm{h}$ and rural roads with a maximum speed of $\leq 100 \mathrm{~km} / \mathrm{h}$ in terms of the maximum crossfall application. These guidelines also retain a maximum value of $7 \%$ for a $400 \mathrm{~m}$ radius, which can be reduced to a minimum of $5 \%$ owing to the justified local conditions.

Table 1 Maximum crossfall in the curve - Austrian guidelines [18]

\begin{tabular}{lccccccccc}
\hline & $\mathbf{R}[\mathrm{m}]$ & $\leq 800$ & 1000 & 1200 & 1400 & 1600 & 1800 & $\geq 2000$ & \\
Speed V $>100 \mathrm{~km} / \mathrm{h}$ & $\mathbf{q}_{\max }[\%]$ & 6 & 5 & 4.5 & 4 & 3.5 & 3 & 2.5 & \\
(Motorways and Expressways Aand S) & $\mathbf{R}[\mathrm{m}]$ & $\leq 400$ & 500 & 600 & 700 & 800 & 900 & 1000 & $\geq 1200$ \\
Speed V $<100 \mathrm{~km} / \mathrm{h}$ & $\mathbf{q}_{\max }[\%]$ & 7 & 5.5 & 4.5 & 4 & 3.5 & 3.5 & 3 & 2.5 \\
\hline (Other classes of Rural roads) & & & & & & & & &
\end{tabular}

The Serbian guidelines [12] (similar to the Austrian guidelines) separate the motorway from the other rural roads by providing separate diagrams for determining the crossfall of the carriageway in the curves by setting the boundary difference across a lane width of $3.5 \mathrm{~m}$ (Figure 3).
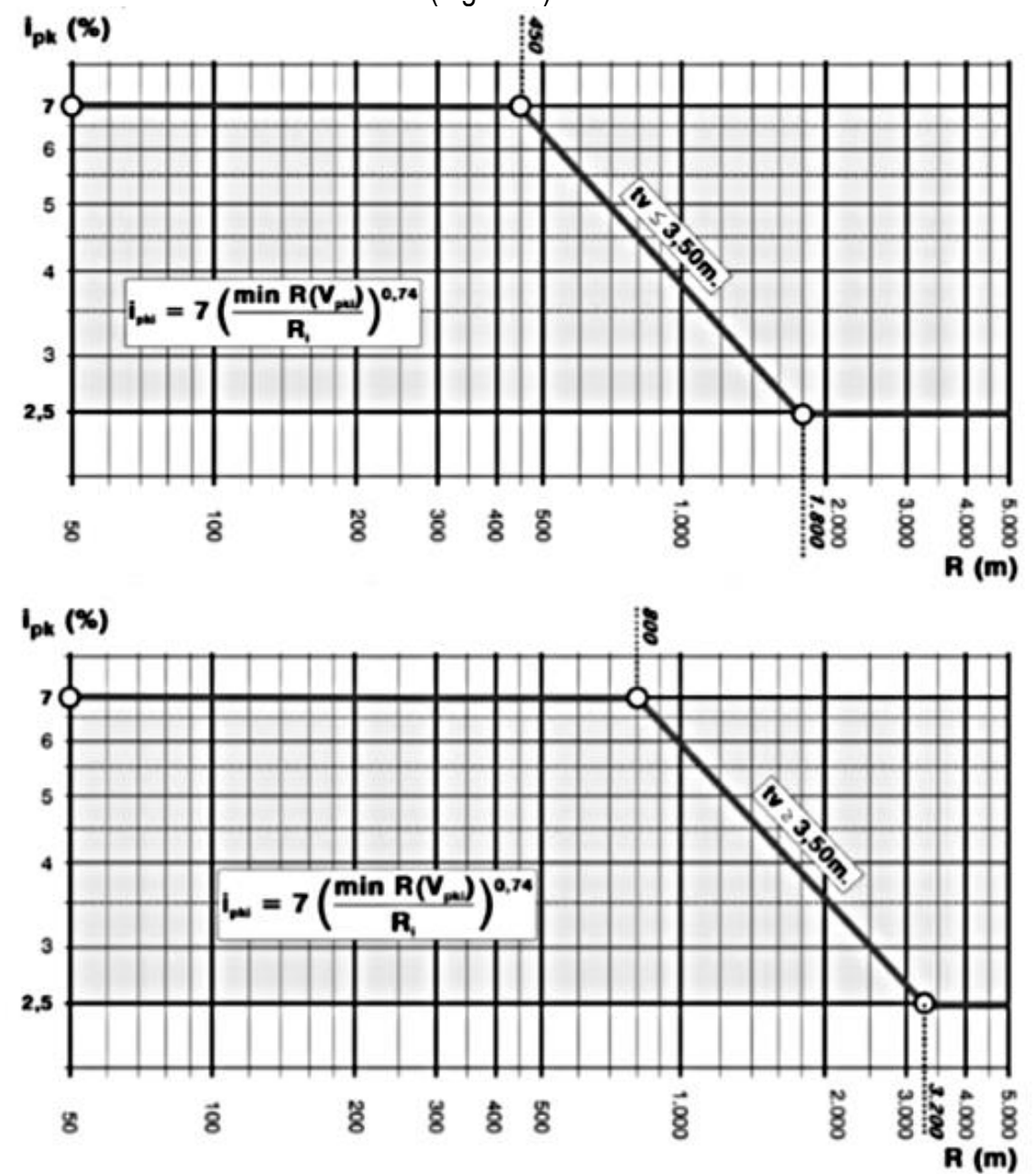

Figure 3 (top) Carriageway crossfall $\mathrm{i}_{\mathrm{pk}}$ for lane widths of up to $3.5 \mathrm{~m}$, (bottom) carriageway crossfall $\mathrm{i}_{\mathrm{pk}}$ for lane widths exceeding $3.5 \mathrm{~m}$ [12] 


\subsection{Second group of guidelines}

As shown in Table 2, the Slovenian guidelines [6] are based on determining the crossfall for the design speed. For example, for a design speed of $60 \mathrm{~km} / \mathrm{h}$, a minimum slope of $2.5 \%$ is determined for a radius of $350 \mathrm{~m}$, and from the above-mentioned research, it is apparent that the operating speeds may be greater than $80 \mathrm{~km} / \mathrm{h}$.

Table 2 Crossfall as a function of curve radius - Slovenian guidelines [6]

\begin{tabular}{ccccccccccc}
\hline $\begin{array}{c}\text { Design } \\
\text { speed }\end{array}$ & \multicolumn{10}{c}{ Minimum radii for different crossfalls (m) } \\
& \multicolumn{10}{c}{ Crossfall } \\
& $2,5 \%$ & $3,0 \%$ & $3,5 \%$ & $4,0 \%$ & $4,5 \%$ & $5,0 \%$ & $5,5 \%$ & $6,0 \%$ & $6,5 \%$ & $7,0 \%$ \\
$30 \mathrm{~km} / \mathrm{h}$ & 70 & 60 & 50 & 45 & 40 & 35 & 33 & 30 & 27 & 25 \\
$40 \mathrm{~km} / \mathrm{h}$ & 125 & 110 & 90 & 80 & 70 & 65 & 60 & 50 & 47 & 45 \\
$50 \mathrm{~km} / \mathrm{h}$ & 200 & 175 & 150 & 127 & 120 & 110 & 98 & 90 & 77 & 75 \\
$60 \mathrm{~km} / \mathrm{h}$ & 350 & 280 & 240 & 210 & 180 & 165 & 150 & 140 & 127 & 125 \\
$70 \mathrm{~km} / \mathrm{h}$ & 500 & 420 & 360 & 320 & 280 & 250 & 230 & 210 & 190 & 175 \\
$80 \mathrm{~km} / \mathrm{h}$ & 700 & 580 & 500 & 420 & 390 & 350 & 320 & 290 & 270 & 250 \\
$90 \mathrm{~km} / \mathrm{h}$ & 1000 & 800 & 700 & 620 & 550 & 490 & 450 & 400 & 370 & 350 \\
$100 \mathrm{~km} / \mathrm{h}$ & 1250 & 1050 & 920 & 780 & 700 & 640 & 580 & 550 & 480 & 450 \\
$110 \mathrm{~km} / \mathrm{h}$ & 1700 & 1400 & 1200 & 1050 & 950 & 850 & 780 & 700 & 650 & 600 \\
$120 \mathrm{~km} / \mathrm{h}$ & 2000 & 1750 & 1500 & 1375 & 1175 & 1050 & 960 & 900 & 840 & 750 \\
$130 \mathrm{~km} / \mathrm{h}$ & 3000 & 2100 & 1800 & 1550 & 1400 & 1250 & 1150 & 1050 & 950 & 900 \\
\hline
\end{tabular}

The Croatian guidelines [5] determine the carriageway crossfall along a curve based on the design (class 1 and 2) or project (class $3,4,5$ ) speed according to the graph in Figure 4, and have higher (slightly safer) criteria than the Slovenian guidelines because, for the design speed of $60 \mathrm{~km} / \mathrm{h}$, the minimum crossfall is for a radius of greater than $520 \mathrm{~m}$. The difference between the design and operating speeds was described earlier.

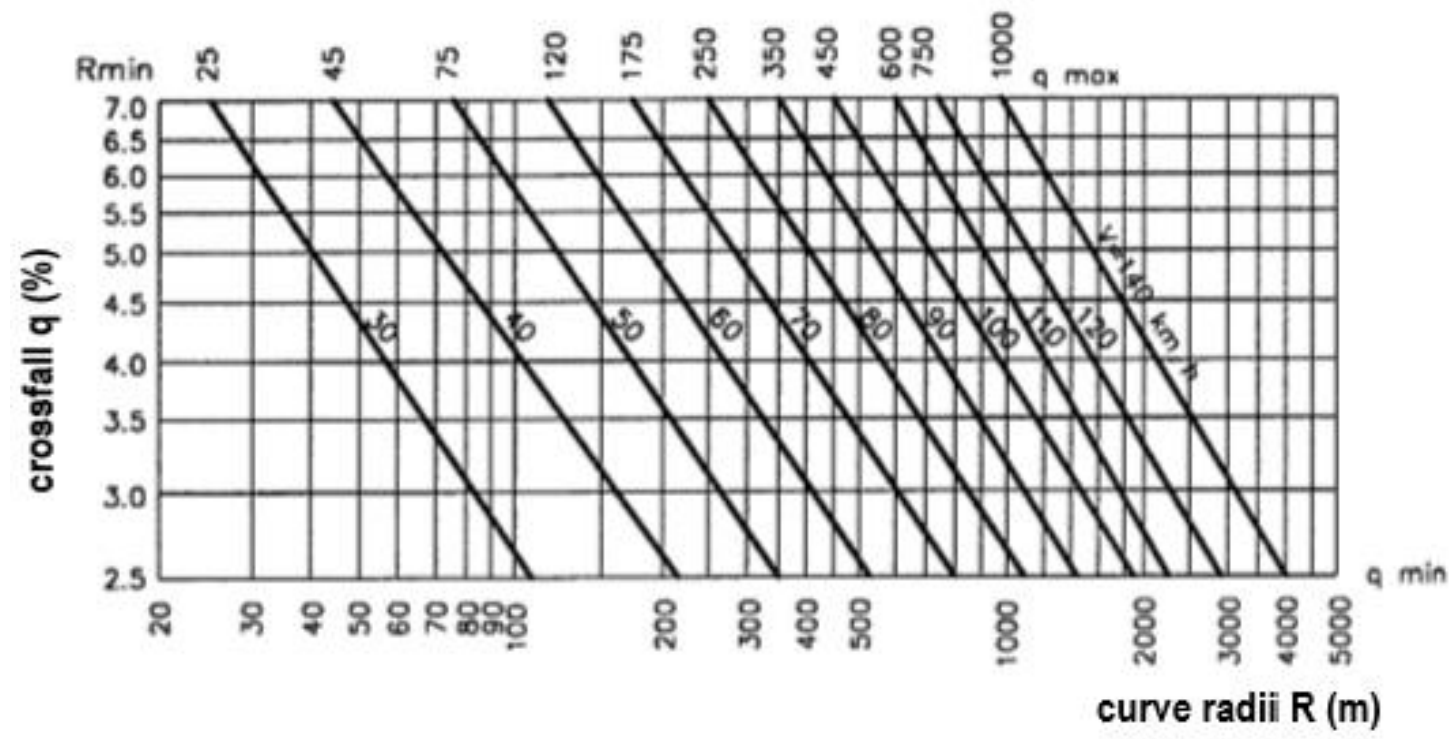

Figure 4 Crossfall as a function of curve radius for design speed $\mathrm{Vr}$ - Croatian guidelines [5]

The Bosnian-Herzegovinian guidelines [4] have a number of fundamental settings that need to be corrected. One of them is the division of roads into technical groups $A, B, C$, and $D$, which are the foundation for the design. For the same design speed, completely different elements of the road geometry can be obtained. As an example, Figures 5 and 6 show graphs for determining the crossfall for technical groups $A$ and $B$. If a road with a speed of $60 \mathrm{~km} / \mathrm{h}$ is illogically (according to these guidelines) classified as technical group A, the minimum crossfall can be applied for a radius of greater than $500 \mathrm{~m}$ (a similar situation as in the Croatian guidelines). If the road is classified into technical group $B$ according to these guidelines, the minimum radius for $q=7 \%$ is $100 \mathrm{~m}$, and for a radius of 
greater than $180 \mathrm{~m}$, the crossfall is $2.5 \%$. This result is quite illogical and does not warrant further comment. In practical terms, in the $\mathrm{B} \& \mathrm{H}$ guidelines, only a technical group $\mathrm{A}$ diagram is applicable.

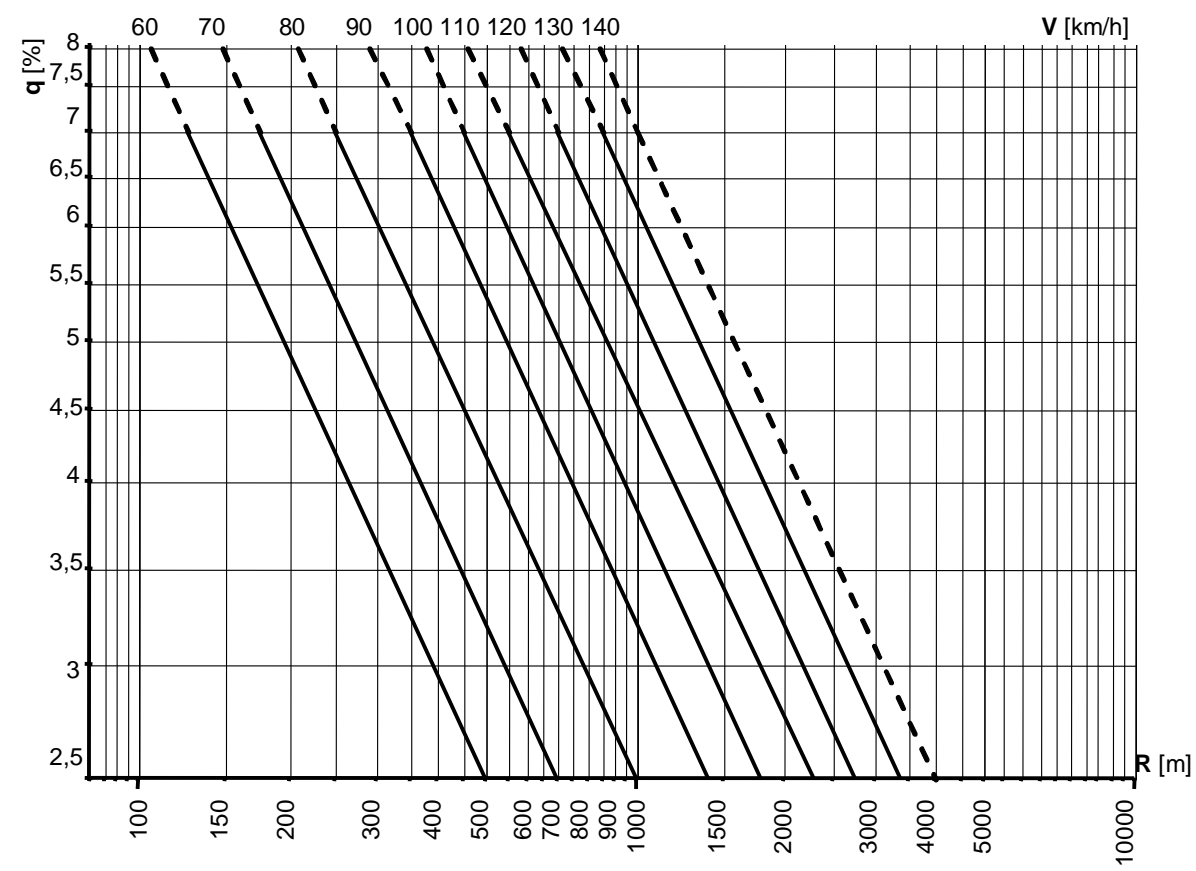

Figure 5 Crossfall for technical group A [4]

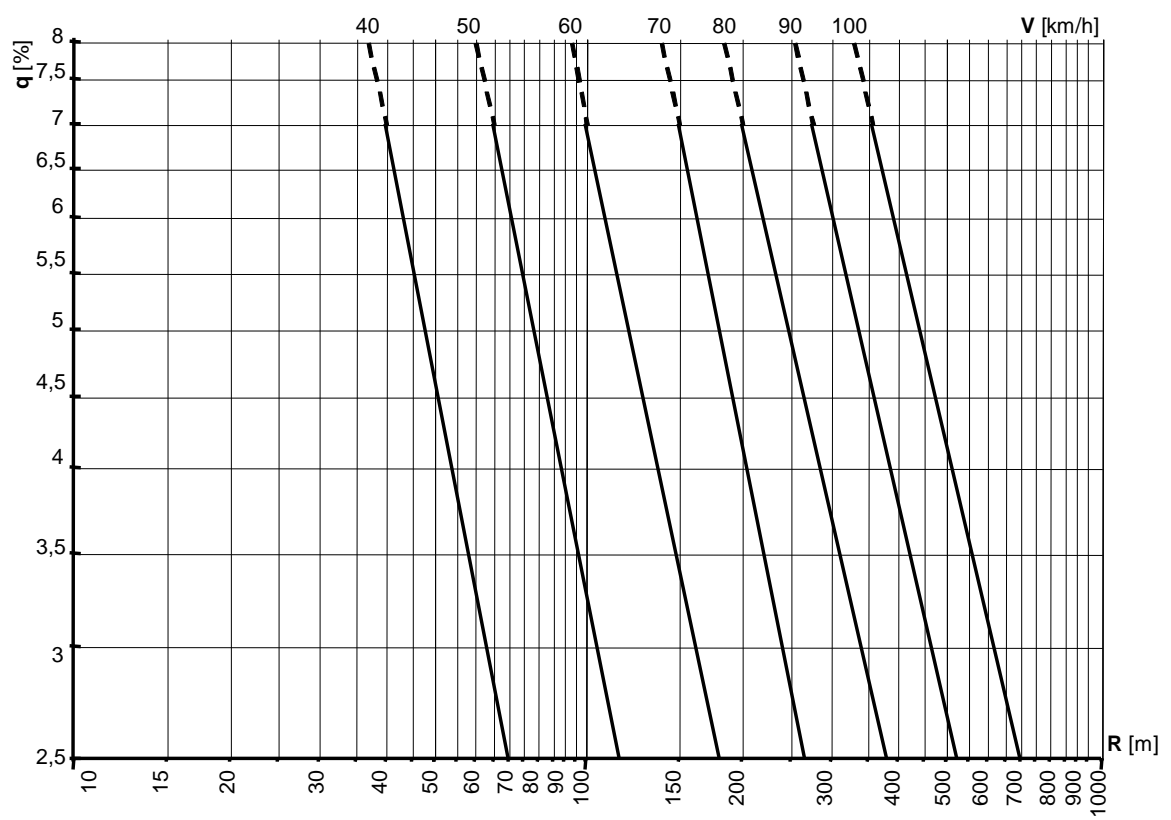

Figure 6 Crossfall for technical group B [4]

\section{DISCUSSION}

Based on the chapter above, the following can be underlined:

- The first group of guidelines has a unique rule for determining the crossfall for all rural roads (excluding motorways): German guidelines [17] for all classes (EKL1 to EKL4), Austrian guidelines [18] for all road speeds of up to $100 \mathrm{~km} / \mathrm{h}$, and Serbian guidelines [12] for all roads with lane widths of up to $3.5 \mathrm{~m}$ (which is indirectly valid for 
speeds of up to $100 \mathrm{~km} / \mathrm{h}$ ). Thus, they all retain the maximum values of the crossfall to certain radius values ( 350 , 400 , and $450 \mathrm{~m}$ ) simply for the operating speed.

- The second group of guidelines for different speeds $(30$ to $130 \mathrm{~km} / \mathrm{h})$ gives different crossfalls. They also define the speeds differently (project, design, and predictability), herein called the design speed (for simplicity), but none are the operating speed, which is also noticeable compared to the first group diagrams.

For a graphical drawing of all guidelines together (Figures 7 and 8), speeds of 80 and $60 \mathrm{~km} / \mathrm{h}$ and lower-class roads were selected. In the case of the Croatian guidelines [5], road classes 3,4 , and 5 were selected for which the project speed can be determined to be up to $80 \mathrm{~km} / \mathrm{h}$ (depending on the degree of restriction). This speed is basic for a crossfall determination.

Figure 7 shows a comparison of the crossfall determination for a design speed of $80 \mathrm{~km} / \mathrm{h}$ according to the previously analyzed guidelines. From the graph, it is apparent that the German guidelines [17] apply a maximum crossfall of $7 \%$ for all classes of rural roads and for all radii below $350 \mathrm{~m}$. The Austrian guidelines [18], which are similar to the German guidelines for speeds $\leq 100 \mathrm{~km} / \mathrm{h}$, apply a maximum $7 \%$ crossfall for radii $\leq 400 \mathrm{~m}$. The Serbian guidelines [18] have the strongest criteria in that the crossfall changes from a maximum of $7 \%$ for radii $\leq$ $450 \mathrm{~m}$ to a minimum of $2.5 \%$ for only radii $\geq 1,800 \mathrm{~m}$ at a lane width of $\leq 3.5 \mathrm{~m}$, which again indicates all rural roads except a motorway, or speeds of up to $100 \mathrm{~km} / \mathrm{h}$.

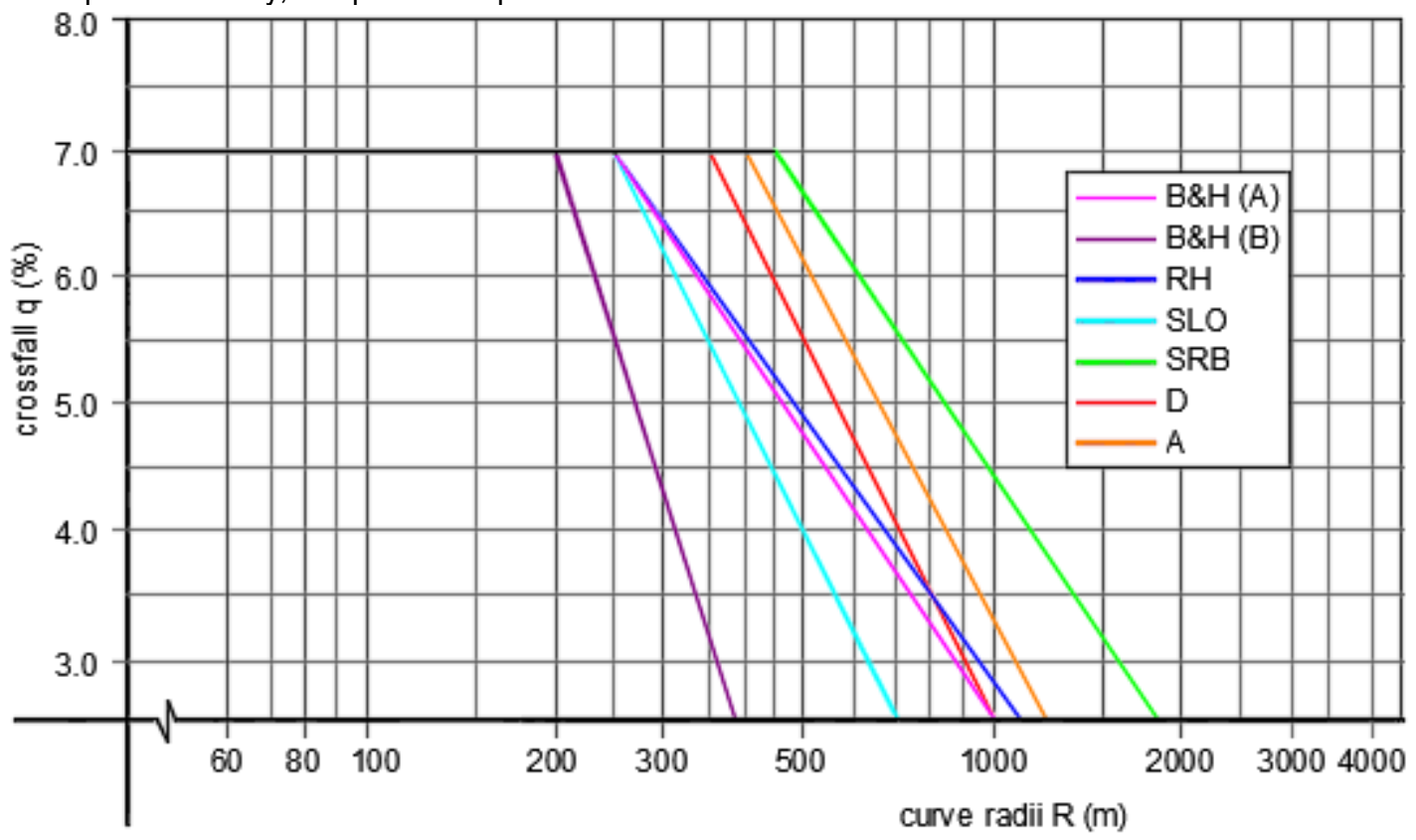

Figure 7 Crossfall according to the different guidelines for speeds of $80 \mathrm{~km} / \mathrm{h}$

Other guidelines such as B\&H [4], HR [5], and SLO [6] apply a crossfall directly to the design speed. Therefore, they do not take into account the introductory fact that all studies [8-11,13] have shown that the operating speed are greater than the design, or the basic assumption regarding the radial stability of the vehicle in curves with radii greater than the minimum. For the conditions of reduced adhesion (which is not so rare), the problem is even more pronounced. By comparing these three guidelines, there are significant differences in the application of the minimum crossfall of $2.5 \%$ in the curves. For example, keeping the design speed of $80 \mathrm{~km} / \mathrm{h}$ in the HR guidelines [5] allows for $\geq 1100 \mathrm{~m}$, whereas SLO [6] allows for $\geq 700 \mathrm{~m}$, and BH [4] provides completely different results depending on the division of the roads according to Technical Groups A, B, and C. The only aspect that makes sense from the perspective of the crossfall determination is technical group $A$, in which $q_{\min }$ is applied for $R \geq 1,000$ $\mathrm{m}$. The graph also shows the crossfall change for technical group B where applying a minimum crossfall for radii $\geq$ $400 \mathrm{~m}$ is allowed.

In recent decades, numerous operating speed models have been developed [11] for use in the design phases to determine the geometrical elements of the alignment by emphasizing the need to define additional criteria in the guidelines to obtain a consistent segment as the final result. 
Analogous crossfall ratios according to different guidelines have also been presented for a speed of $60 \mathrm{~km} / \mathrm{h}$ (Figure 8), where the difference in the ratio between the crossfall and radius is even more pronounced.

For example, a section of an existing road (class 3 , design speed $=$ project speed $=60 \mathrm{~km} / \mathrm{h}$ such as with the section upon which the measurements were conducted, as shown in Figure 1) was selected for reconstruction and improved safety. The German guidelines [17] should be representative of the first group; and the Croatian [5] guidelines, representative of the second group. From Figure 8 , it can be seen that for $R=350 \mathrm{~m}$, according to the Croatian guidelines, the crossfall is $q=3.7 \%$, and according to the German guidelines, the maximum crossfall is $q$ $=7 \%$.

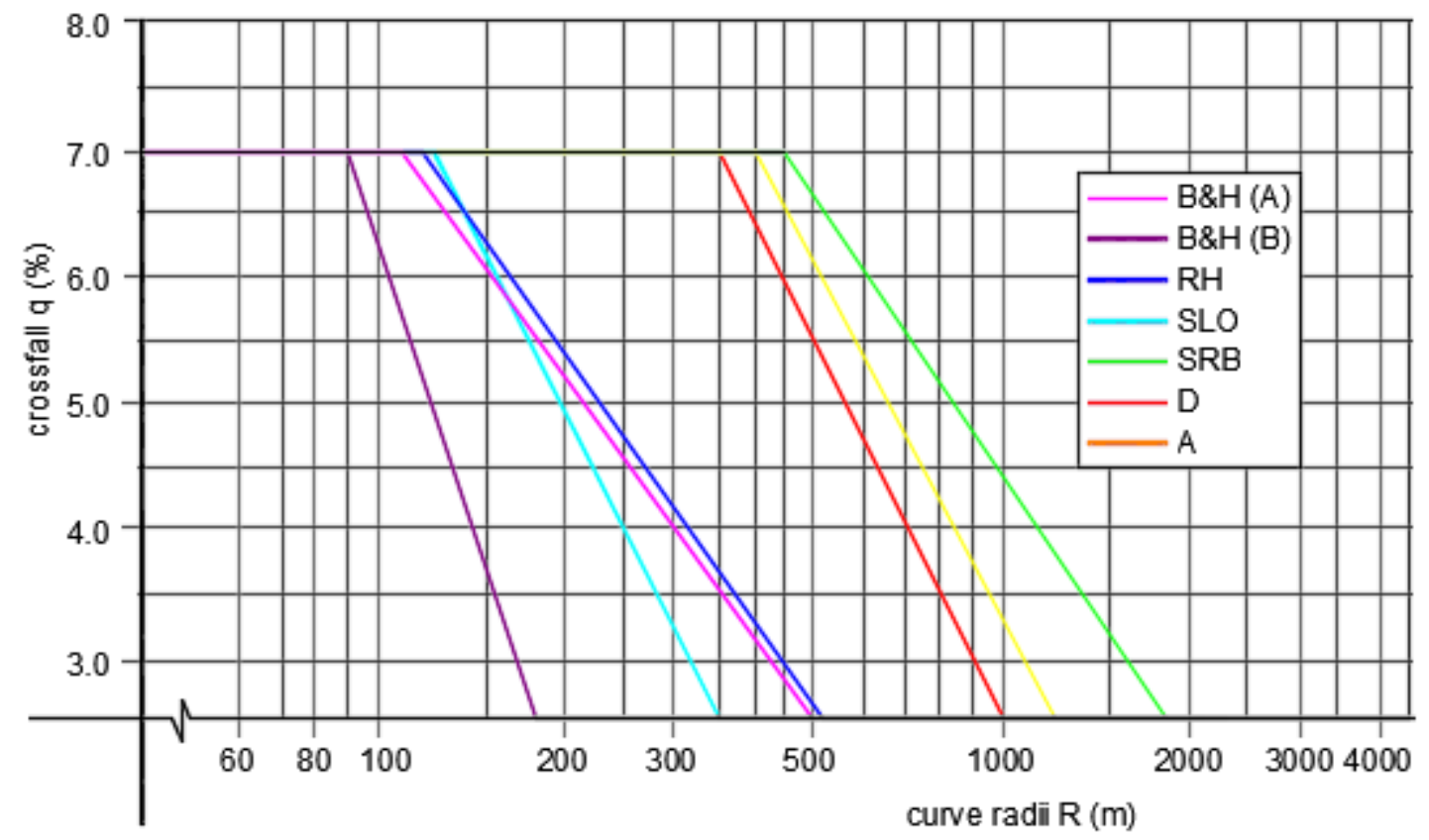

Figure 8 Crossfall according to the different guidelines for speeds of $60 \mathrm{~km} / \mathrm{h}$

The different approach adopted in the new German guidelines [17] leaves the concept of operating speeds and introduces the concept of design road classes [19]. As defined in the guidelines, this means the following: The road should be designed in such a way as to offer a very limited number of road types to the road user, and within each type of road, the characteristics should be as uniform as possible. All features together should make the road self-explanatory, which means that the experienced driver knows a typical combination of elements for each type of road and what kind of driving corresponds to the characteristics of a certain type of road. The driver should be able to recognize the type based on the geometric properties and types of intersections. This requires that the design elements within one type of road are extremely similar, and that the elements of different types of road be distinguished as much as possible. As a result, this concept produced four types of rural roads classified into the design class. As previously mentioned, this approach also includes a crossfall application as a function of the operating speed.

\section{CONCLUSION}

The analysis conducted in this paper shows that the application of a carriageway crossfall (problem/solution) should be considered from two aspects. One aspect is designing new sections of rural roads with speeds of less than 100 $\mathrm{km} / \mathrm{h}$, whereas the other is an improvement (increase in safety) of existing two-lane roads (motorways are dealt with separately). When designing new road segments, regardless of which concept is applied (the operating speed or design class of a self-explaining road), the problem of a crossfall determination in the curves is automatically solved.

For an existing road network, it is insufficient to introduce new principles into the guidelines. It is practically impossible to achieve consistency of a route by improving the existing road and can only be achieved with a new Lovrić, I, Čutura, B, Cvitanić, D 
section. The solution is to introduce operating speed principles to increase safety on an existing road network. For a determination of the crossfall in curves with radii larger than the minimum, it is clear that the maximum crossfall should be kept to the limit where the values of the design and operating speeds are assumed at almost the same values.

\section{References}

[1] Lamm, R.; Psarianos, B.; Choueiri, E. M.; Soilemezoglou, G. 1995: A Practical Safety Approach to Highway Geometic Design International Case Studies: Germany, Greece, Lebanon, and the United States, Proceedings of the International Sym posium on Highway Geometric Design Practices, Texas Transportation Institute, Boston, Massachusetts, pp. 9:19:14.

[2] Republic of Croatia, the Ministry of the Interior, Secretariat of the Ministry - Department for Strategic Planning, Analysis and Development 2014. Bilten o sigurnosti cestovnog prometa 2013. [Road Safety Bulletin 2013]. http://umw.mup.hr/UserDocsImages/statistika/2014/bilten_promet_2013.pdf, Accessed 11 March 2019 (in Croatian)

[3] ERA-NET ROAD 2012. Safety at the Heart of Road Design, Final Report of the ERA-NET programme

[4] Službeni glasnik Bosne i Hercegovine 13/2007: Pravilnik o tem eljnim uvjetima koje javne ceste, njihovi elementi i objeki na njima moraju ispunjavati s aspekta sigurnosti prometa (BH Guidelines for the Design of Rural Roads), Sarajevo (in Croatian)

[5] Narodne novine Republike Hrvatske NN 110/01, 2001. Pravilnik o osnovnim uvjetima kojima javne ceste izvan naseljai njihovi elementi moraju udovoljavati sa stajališta sigurnosti prometa (Croatian Guidelines for the Design of Rural Roads), Zagreb (in Croatian)

[6] Uradni list Republike Slovenije RS 91/2005. Pravilnik o projektiranju cest (Slovenian Guidelines for the Design of Rural Roads), Ljubljana (in Slovenian)

[7] Maljković, B., Cvitanić, D. 2016: Evaluation of design consistency on horizontal curves for two-lane state roads in terms of vehicle path radius and speed, the Baltic Journal of Road and Bridge Engineering, 11(2), pp. 127-135, http://dx.doi.org/10.3846/bjrbe.2016.15

[8] Cvitanić, D., Maljković, B. 2017: Operating speed models of two-lane rural state roads developed on continuous speed data, Tehnicki Vjesnik - Technical Gazette, 24(6), pp. 1921, https://doi.org/10.17559/TV-20150304133437

[9] Chowdhury, M.A.; Warren, D.L.; Bissell, H. 1991: Analysis of Advisory Speed Setting Criteria, Public roads, 55(3), pp. 65-71

[10] McLean, J. R. 1988. Speeds, Friction Factors and Alignment Design Standards, Australian Road Research

[11] Transport Research Bord TRB 2011: Modeling Operating Speed, Synthesis report, Washington DC, http://onlinepubs.trb.org/onlinepubs/circulars/ec151.pdf, Accessed 11 March 2019

[12] Službeni glasnik Republike Srbije 50/2011: Pravilnik o uslovima koje sa aspekta bezbednosti saobraćaja moraju da ispunjavaju putni objekti i drugi elementi javnog puta (Serbian Guidelines for the Design of Rural Roads), Beograd (in Serbian)

[13] Vukoje, B. 2013: Operativne brzine u horizontalnim krivinama (Operating speed in horizontal curves), UHGF, 1stmeeing of young researchers in the field of civil engineering, Split, https://bib.irb.hr/datoteka/646772.ZT Split 2013 Vukoje.pdf, Accessed 11 March 2019 (in Croatian)

[14] Cvitanić, D., Maljković, B., Breški, D. 2013: Methods for ensuring consistency of horizontal alignment elements, GRAĐEVINAR, 64 (5), pp. 385-393

[15] Forschungsgesellschaft für Straßen - und Verkehrswesen, Arbeitsgruppe "Straßenentwurf": Die Richtinien für die Anlage von Straßen - Teil: Linienführung (kurz RAS-L), Germany, 1973, 1984, 1995 (in German)

[16] Austroroads: Rural Road Design 1997: Guide to the Geometric Design of Rural Roads, Sydney, Australia,

[17] Forschungsgesellschaft für Straßen - und Verkehrswesen (FGSV) 2012: Richtlinien für die Anlage von Landstrassen (RAL) (German Guidelines for the Design of Rural Roads), Cologne (in German)

[18] Österreichische Forschungsgesellschaft Straße - Schiene - Verkehr 2014: Straßenplanung, FreilandStraßen, Trassierung, Linienführung und Trassierung RVS 03.03.23, (Austrian Guide lines for the Geometric Design of Highways), Wien (in German)

[19] Lippold, C., Lemke, K., Jährig, T., Stöckert, R. 2015:- Country reportGermany, The newGeneration ofDesign Guidelines for Roads and Motorways in Germany, 5 th International Sym posium on Highway Geometric Design, Vancouver, https://static1.squarespace.com/static/51cc8d46e4b0b242fc8d0f33/t55c4f627e4b0852b09fa899a/1438971431239/172 +Germany+Country+Report.pdf, Accessed 11 March 2019

Please cite this article as:

Lovrić, I.; Čutura, B.; Cvitanić, D.: Dependence of carriageway crossfall on operating speed, Electronic Journal of the Faculty of Civil Engineering Osijek-e-GFOS, 2019, 18, pp. 48-56, https://doi.org/10.13167/2019.18.5 